\title{
Is Rhizoplaca (Lecanorales, lichenized Ascomycota) a monophyletic genus?
}

\author{
U. Arup and M. Grube
}

\begin{abstract}
Rhizoplaca Zopf is a genus characterized by an umbilicate thallus with an upper and a lower cortex, as well as a cupulate hypothecium. It has been considered to be related to Lecanora Ach., the type genus of the Lecanoraceae and, in particular, to the lobate species of this genus. The phylogeny of Rhizoplaca, the monotypic Arctopeltis thuleana Poelt, and a number of representatives of different groups of Lecanora is studied, using sequences from the nuclear ribosomal internal transcribed spacer (ITS) regions. The results suggest an origin for Rhizoplaca species within the large genus Lecanora. A well-supported monophyletic assemblage includes the umbilicate type species Rhizoplaca melanophthalma (DC.) Leuck. \& Poelt, the lobate Lecanora novomexicana H. Magn., and five vagrant Rhizoplaca species. Rhizoplaca chrysoleuca (Sm.) Zopf and Rhizoplaca subdicrepans (Nyl.) R. Sant. form a separate well-supported group and Rhizoplaca peltata (Ram.) Leuck. \& Poelt is more closely related to Lecanora muralis (Schreb.) Rabenh. Together with data on secondary chemistry, the results show that the umbilicate thallus with a lower and an upper cortex, as well as apothecia with a cupulate hypothecium found in Rhizoplaca and A. thuleana, have developed several times in independant lineages in Lecanora. The thallus morphology in lecanoroid lichens is highly variable and does not necessarily reflect phylogenetic relationships.
\end{abstract}

Key words: Rhizoplaca, Lecanora, Lecanorales, phylogeny, ITS.

Résumé : Le genre Rhizoplaca Zopf est caractérisé par un thalle ombiliqué muni de cortex supérieur et inférieur, ainsi que d' un hypothèce cupulé. On a considéré qu'il serait relié au Lecanora Ach., le genre type des Lecanoraceae, et particulièrement aux espèces lobées de ce genre. En utilisant les séquences des régions de l'espaceur ribosomal nucléaire interne transcrit (ITS), les auteurs ont étudié la phylogénie des Rhizoplaca, de l'Arctopeltis thuleana Poelt monotypique, et d'un nombre de représentants de différents groupes de Lecanora. Les résultats suggèrent une origine pour les espèces de Rhizoplaca à l'intérieur du genre Lecanora étendu. Un regroupement monophylétique bien supporté inclut: l'espèce type ombiliquée Rhizoplaca melanophthalma (DC.) Leuck. \& Poelt, l'espèce lobée Lecanora novomexicana H. Magn., et cinq espèces mal définies de Lecanora. Le Rhizoplaca chrysoleuca (Sm.) Zopf et le Rhizoplaca subdicrepans (Nyl.) R. Sant. forment un groupe séparé, bien supporté, et le Rhizoplaca peltata (Ram.) Leuck \& Poelt est plus étroitement apparenté au groupe Lecanora muralis (Schreb.) Rabenh. Pris ensemble avec les résultats de la chimie secondaire, les résultats montrent que le thalle ombiliqué muni de cortex inférieur et supérieur, ainsi que d'apothèce avec hypothèce cupulé qu'on retrouve chez les Rhizoplaca et l' A. thuleana, se sont développés plusieurs fois dans des lignées indépendantes chez les Lecanora. La morphologie du thalle, chez les lichens lecanoroïdes, est très variable et ne reflète pas nécessairement les relations phylogénétiques.

Mots clés : Rhizoplaca, Lecanora, Lecanorales, phylogénie, ITS.

[Traduit par la Rédaction]

\section{Introduction}

Thallus morphology has traditionally been used in lichen systematics to distinguish taxa at different levels. For example, the family Caloplacaceae, with crustose members, was distinguished from the family Teloschistaceae, which includes foliose to fruticose lichens (Zahlbruckner 1926). Within the latter, the genus Xanthoria (Fr.) Th. Fr. was separated from the genus Teloschistes Norman mainly by a foliose thallus

Received January 18, 1999.

U. Arup. Department of Systematic Botany, University of Lund, Östra Vallgatan 14-20, SE-223 61 Lund, Sweden. M. Grube. ${ }^{1}$ Institut für Botanik, Karl-Franzens-Universität Graz, Holteigasse 6, A-8010 Graz, Austria.

${ }^{1}$ Author to whom all correspondence should be addressed (e-mail: martin.grube@kfunigraz.ac.at). with rhizines versus a fruticose thallus. Another case is the separation of the crustose Buelliaceae from the foliose to fruticose Physciaceae; analogous examples are also found within the large family Lecanoraceae. Lobate species of Lecanora Ach. have primarily been treated as subgenus Placodium, and the two genera Arctopeltis Poelt (Poelt 1983) and Rhizoplaca Zopf (Leuckert et al. 1977) have been separated from the genus Lecanora mainly by their umbilicate thalli with well-developed upper and lower cortices.

While this classification scheme works well for many species, those with intermediate thallus characters are difficult to classify using traditional generic concepts. During the last decade, ascomatal characters have become more and more important in the classification of families (e.g., Hafellner 1984) and genera (e.g., Thell and Goward 1996). However, there is sometimes little variation of these characters within a family or between genera and no further support for genera that are characterized mainly by thallus morphology. In such 
cases, molecular data offer alternatives for evaluating proposed taxonomy.

The genus Rhizoplaca comprises saxicolous species containing usnic acid that are more or less umbilicate and fixed to the substrate or fruticose and free-living as vagrant lichens (Ryan and Nash 1997). Originally, this genus was segregated from the genus Squamaria DC. (now Squamarina Poelt) by Zopf (1905) on the basis of a single central strong rhizoid that attaches the lichen to the substrate. Vagrant species without this rhizoid were later included (Ryan and Nash 1997). The genus was also recognized by Choisy (1929), who described it under the later synonym Omphalodina M. Choisy. Choisy (1929) used the umbilicate thallus morphology and the occurrence of two algal layers in the apothecium to characterize the genus. However, the latter characteristic was subsequently found to be atypical for the genus (Leuckert et al. 1977).

Poelt (1958) adopted a very wide circumscription of the genus Lecanora and included the genus Rhizoplaca as section Omphalodina in the subgenus Placodium. Almost 20 years later, Leuckert et al. (1977) once again raised the group to generic level, using the oldest name available, $R h i$ zoplaca. The authors' arguments for this treatment were that the genus is homogeneous in morphology, ecology, distribution, and chemistry, and that no intermediate forms occur between Rhizoplaca and other groups within Lecanora, at least not within the "Lecanora subfusca" group (= the Lecanora allophana group in a wider sense), which includes the type species of the genus, L. allophana. Rhizoplaca could, according to the authors, be distinguished by the umbilicate growth form, distinct upper cortex, rather loose medulla, and thick lower cortex. Since then, the status of the genus has not been questioned, but Ryan and Nash (1997) have pointed out that the boundaries between Lecanora and Rhizoplaca need further clarification. However, because of the cupulate structure of the apothecia, it has even been proposed that the genus belongs to another family, the Parmeliaceae (Lumbsch et al. 1991), which can be characterized by a cupula structure in the ascomata, besides differences in pycnidial characters. This view was rejected by Roux et al. (1993), who showed that the pseudoparenchymatic cupula in the Parmeliaceae is different from superficially similar structures in Lecanora.

It is likely that thallus characteristics have evolved in parallel in lichen-forming ascomycetes, as has been shown for "cladoniiform" lichens by Stenroos and DePriest (1998). Also, phylogenetic studies on Lecanora subgenus Placodium using DNA sequence data from the internal transcribed spacer (ITS) regions of nuclear ribosomal DNA, indicated that growth forms may vary considerably within some species and groups of Lecanora (Arup and Grube 1998). Because these results already affect the traditional infrageneric classification of Lecanora, we were interested in reinvestigating the generic boundaries between Lecanora and Rhizoplaca and in re-evaluating the role of morphological characters in generic delimitation.

\section{Materials and methods}

Lichen material for this study was borrowed from the herbaria of Arizona State University (ASU), University of Copenhagen (C), and Karl-Franzens-Universität Graz (GZU), and from the private herbaria of U. Arup and H.R. Rosentreter. The growth form and collection sites of the species or specimens studied are listed in Table 1 .

Total DNA was extracted from individual thalli using a modified CTAB method (Cubero et al. 1999). DNA extracts were used for PCR amplification of the ITS regions, including the 5.8S gene of the nuclear rDNA. The primers used for amplification were ITS1F (Gardes and Bruns 1993) and ITS4 (White et al. 1990). The PCR reaction mixture $(50 \mu \mathrm{L} ; 10 \mathrm{mM}$ Tris $(\mathrm{pH} 8.3), 50 \mathrm{mM} \mathrm{KCl}$, $1.5 \mathrm{mM} \mathrm{MgCl} 2$, and $50 \mu \mathrm{g}$ gelatine) contained $1.25 \mathrm{U}$ Dynazyme Taq polymerase (Finnzymes), $0.2 \mathrm{mM}$ of each of the four dNTPs, $0.5 \mu \mathrm{M}$ of each primer, and ca. 10-50 ng of genomic DNA. Products were either PEG-precipitated or cleaned using QIAGEN $^{\circledR}$ quick spin columns (Qiagen). Both complementary strands were sequenced, using the dRhodamine Terminator Cycle Sequencing Ready Reaction Kit or Dye Terminator Cycle Sequencing Ready Reaction Kit (Perkin Elmer), according to the manufacturer's instructions. Sequences were run either on a ABI310 or a ABI373 automated sequencer (ABI). Initial alignments of sequences using the Pile-up program of the Wisconsin package (Genetics Computer Group (GCG) sequence analysis software) were manually optimized.

Parsimony and maximum-likelihood analyses were carried out using PAUP*4.0 (Swofford 1999). Without the flanking regions of the small subunit and large subunit rDNA, the ITS alignment included 581 sites. In-dels and ambiguously aligned parts were excluded (62 sites); the matrix included 209 informative characters. Gaps were treated as missing values. In a first parsimony analysis, the matrix was subjected to 1000 replicates of random sequence additions using heuristic searches, using tree bisection and reconnection (TBR) branch swapping. One thousand bootstrap replications were performed. A second parsimony analysis was carried out with the same parameters, but this analysis included only species groups (that were found in the first analysis) with variable growth types and that contained usnic acid as a main compound. The restricted data set was also subjected to a maximum-likelihood analysis as implemented in PAUP*4.0, using 1000 replicates of random addition sequences. Nucleotide frequencies were determined empirically, using two substitution types, and the transition/transversion ratio was set to 1.5. All sites were assumed to evolve at the same rate, using a Hasegawa-Kishina-Yano model, and a molecular clock was not enforced. To test the hypothesis that Rhizoplaca is monophyletic, Kishino-Hasegawa tests, as implemented in PAUP*4.0, were applied.

The alignment and further data about the specimens used in this study can be obtained from the authors upon request. The newly produced sequences are deposited in EMBL/GenBank. GenBank accession numbers are given in Table 1.

Protoparmelia badia (Hoffn.) Hafellner was used as the outgroup in our analyses. This lecanoroid lichen was always outside the Lecanora clade in preliminary analyses, in which Parmelia sulcata Taylor and Hypogymnia physodes (L.) Nyl. (Parmeliaceae) were used as outgroups (data not shown). Arctopeltis thuleana was also included, because it has an umbilicate thallus, but it has usually been treated separately from Rhizoplaca in the literature.

\section{Results}

Six most-parsimonious trees with a length of 880 steps (consistency index $=0.433$; retention index $=0.628$ ) were found by a heuristic search using $P$. badia as outgroup. One of these trees is shown in Fig. 1. The trees are similar to each other in topology, with only slight re-arrangements in the group containing Rhizoplaca melanophthalma. The crustose groups of Lecanora rupicola (L.) Zahlbr. and L. allophana Nyl. (= the former subfusca group in a restricted 
Table 1. The species and specimens studied, with their GenBank accession numbers and origin.

\begin{tabular}{|c|c|c|}
\hline Species or specimen & GenBank accession No. & Origin \\
\hline Arctopeltis thuleana Poelt & AF159926 & Greenland \\
\hline Lecanora achariana A. L. Sm. & AF070019 & Sweden \\
\hline Lecanora albescens (Hoffm.) Branth \& Rostr. & AF070033 & Sweden \\
\hline Lecanora allophana Nyl. & AF159939 & Austria \\
\hline Lecanora campestris (Schaer.) Hue & AF159930 & Sweden \\
\hline Lecanora chlorophaeodes Nyl. & AF159927 & Norway \\
\hline Lecanora concolor Ramond & AF070037 & Italy \\
\hline Lecanora conizaeoides Nyl. ex Crombie & AF189717 & Sweden \\
\hline Lecanora contractula Nyl. & AF070032 & Quebec \\
\hline Lecanora dispersoareolata (Schaer.) Lamy & AF070016 & Austria \\
\hline Lecanora epibryon (Ach.) Ach. & AF070014 & Austria \\
\hline Lecanora garovaglii (Körber) Zahlbr. & AF189718 & Austria \\
\hline Lecanora intricata (Ach.) Ach. & AF070022 & Austria \\
\hline Lecanora macrocyclos (H. Magn.) Degel. & AF159933 & Sweden \\
\hline Lecanora muralis (Schreb.) Rabenh. & AF159922 & Austria \\
\hline Lecanora novomexicana $\mathrm{H}$. Magn., U162 & AF159923 & New Mexico \\
\hline Lecanora novomexicana $\mathrm{H}$. Magn., U363 & AF159945 & Arizona \\
\hline Lecanora opiniconensis Brodo & AF159928 & Arizona \\
\hline Lecanora phaedrophthalma Poelt & AF159938 & Tibet \\
\hline Lecanora polytropa (Ehrh. ex Hoffm.) Rabenh. & AF070017 & Austria \\
\hline Lecanora pruinosa Chaub. & AF070018 & Italy \\
\hline Lecanora reuteri Schaer. & AF070026 & Austria \\
\hline Lecanora saligna (Schrader) Zahlbr. & AF189716 & Sweden \\
\hline Protoparmelia badia (Hoffm.) Hafellner & AF070023 & Austria \\
\hline Rhizoplaca cerebriformis Ryan ined. & AF159942 & Idaho \\
\hline Rhizoplaca chrysoleuca (Sm.) Zopf, U192 & AF159924 & Arizona \\
\hline Rhizoplaca chrysoleuca (Sm.) Zopf, U302 & AF159940 & Kazakhstan \\
\hline Rhizoplaca cylindrica Ryan ined. & AF159941 & Idaho \\
\hline Rhizoplaca haydenii (Tuck.) Follm. & AF159937 & Idaho \\
\hline Rhizoplaca idahoensis Rosentreter ined. & AF159943 & Idaho \\
\hline Rhizoplaca melanophthalma (DC.) Leuck. \& Poelt, U219 & AF159929 & Arizona \\
\hline Rhizoplaca melanophthalma (DC.) Leuck. \& Poelt, U278 & AF159934 & Arizona \\
\hline Rhizoplaca melanophthalma (DC.) Leuck. \& Poelt, U281 & AF159935 & Austria \\
\hline Rhizoplaca peltata (Ram.) Leuck. \& Poelt, U198 & AF159925 & Arizona \\
\hline Rhizoplaca peltata (Ram.) Leuck. \& Poelt, U282 & AF159936 & British Columbia \\
\hline Rhizoplaca subdiscrepans (Nyl.) R. Sant. & AF159946 & Minnesota \\
\hline Rhizoplaca subidahoensis Rosentreter ined. & AF159944 & Idaho \\
\hline
\end{tabular}

sense) are basal to a branch supported by a bootstrap value of $87 \%$. This branch includes the "Lecanora dispersa" group (here represented by Lecanora pruinosa, L. albescens, Lecanora reuteri, Lecanora contractula, and Arctopeltis thuleana) and species groups characterized by usnic acid as a main secondary compound. The $L$. dispersa group also includes an umbilicate species, A. thuleana. All Rhizoplaca species studied branch with the taxa containing usnic acid, as do Lecanora species with various types of growth forms. The Rhizoplaca species do not form a monophyletic branch, but group with different Lecanora species. A number of Rhizoplaca species (group B, Fig. 1), including the umbilicate type species $R$. melanophthalma, group together with Lecanora novomexicana, and this topology has $100 \%$ bootstrap support. Two other umbilicate species, Rhizoplaca peltata and Rhizoplaca chrysoleuca, do not group with this main assemblage of Rhizoplaca species, but appear elsewhere in the tree (groups A and C, Fig. 1). Species with lobate growth are found in the Lecanora muralis group, which is supported by a $94 \%$ bootstrap value. With $71 \%$ support, $R$. peltata appears as a sister branch to this clade. Rhizoplaca chrysoleuca and Rhizoplaca subdiscrepans are supported as a separate group with $97 \%$ support. Analyses under the constraints that Rhizoplaca is monophyletic and both Rhizoplaca and Lecanora (including Arctopeltis) are monophyletic yielded significantly longer trees, which were rejected in a Kishino-Hasegawa test (Table 2). Similar results were also obtained in a restricted analysis that included species groups with usnic acid as a major compound and groups with various growth forms (Fig. 2). In this analysis, six most-parsimonious trees (with a length of 503 steps) with a higher consistency (consistency index $=0.567$; retention index $=0.677$ ) than was found in the larger analysis were obtained. One of the trees, corresponding to the tree obtained in maximum-likelihood analysis, is shown in Fig. 2. Constraint trees with Rhizoplaca as a monophyletic genus were rejected in a Kishino-Hasegawa test (Table 2).

The differences in the ITS sequences between the different species of the core group of Rhizoplaca are generally small. The branch lengths separating the vagrant species of 
Fig. 1. One of six most-parsimonious trees of a phylogenetic analysis of the ITS regions and the 5.8S region of Lecanora, Arctopeltis, and Rhizoplaca, using Protoparmelia badia as the outgroup taxon. Bootstrap percentages greater than 50\% are indicated. Rhizoplaca species are written in boldface type. Groups A-C are discussed in the text.

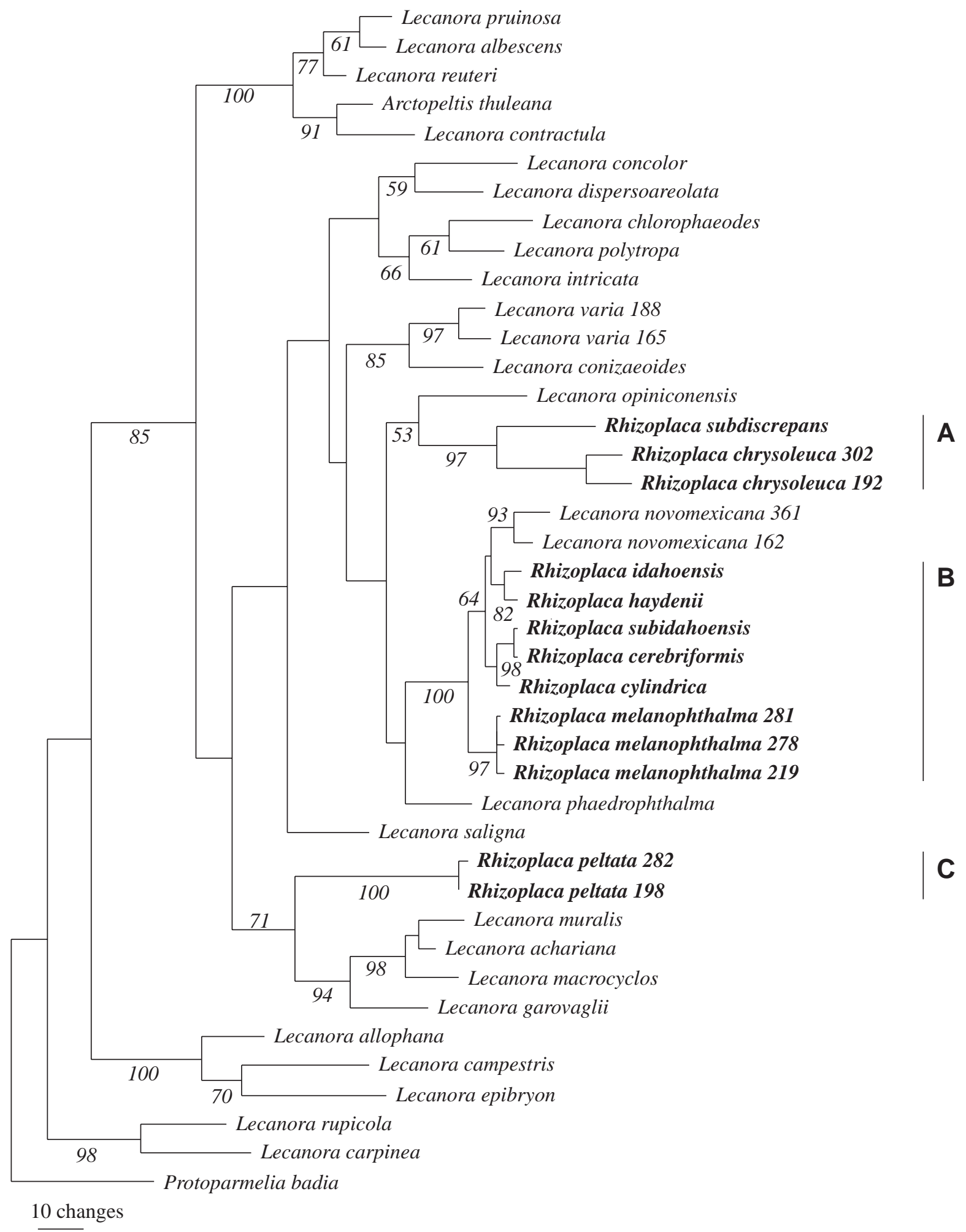

this core group are not longer than the infraspecific branch lengths of, for example, $R$. melanophthalma or $R$. peltata. Only in the $R$. chrysoleuca clade did we observe longer branches, both between $R$. subdiscrepans and within $R$. chrysoleuca.

\section{Discussion}

Rhizoplaca is a well-accepted genus in many lichenology textbooks and floras, and it is generally assumed that the higher organization with an umbilicate to foliose thallus rep- 
Table 2. Likelihood variance tests using the method of Kishino and Hasegawa (1989).

\begin{tabular}{lllll}
\hline (A) Parsimony scores for trees that include all species in the study. & & \\
\hline Tree & Length & Length difference & SD & Significantly longer \\
\hline MP 1 & 880 & (Best) & & \\
MP 2 & 880 & 0 & 1.41761 & No \\
Rhizoplaca monophyletic & 908 & 28 & 7.78065 & Yes \\
Rhizoplaca monophyletic & 908 & 28 & 7.65041 & Yes \\
Rhizoplaca and Lecanora monophyletic & 926 & 46 & 9.39671 & Yes
\end{tabular}

(B) Likelihood scores for trees that include species groups with usnic acid as a major compound and with variable growth.

\begin{tabular}{llccc}
\hline Tree obtained from the restricted data set & ln likelihood & Difference in ln likelihood & SD & Significantly longer \\
\hline MP 1 & 2414.13672 & (Best) & & \\
MP 2 & 2414.40925 & 0.27253 & 1.02431 & No \\
Rhizoplaca monophyletic 1 & 2467.31024 & 53.17352 & 15.09735 & Yes \\
Rhizoplaca monophyletic 2 & 2467.60100 & 53.46428 & 15.27025 & Yes \\
ML & 2414.13672 & 0.00000 & 0.00000 & No \\
ML Rhizoplaca monophyletic & 2473.78242 & 59.64570 & 14.96177 & Yes
\end{tabular}

Note: SD is the statistical standard deviation between trees. If more than one tree was found by heuristic searches (see text), only two trees are represented in the table. MP, most-parsimonious tree; ML, maximum-likelihood tree.

resents a natural group. To evaluate this hypothesis, we selected representative taxa of Rhizoplaca that vary in thallus morphology, chemistry, disc color, and ecology. The type species, $R$. melanophthalma, as well as $R$. peltata and $R$. chrysoleuca, have umbilicate thalli (Figs. 3-4), whereas Rhizoplaca haydenii and some other species (see Fig. 2) have more or less fruticose types of thallus growth. A complete sampling of all Rhizoplaca species was not attempted, because more detailed work on species delimitation in this genus is underway elsewhere.

Our analyses indicate that the generally accepted concept of Rhizoplaca as a genus separate from Lecanora can be rejected. The Rhizoplaca species do not form a monophyletic group but appear on three different branches of the tree. Rhizoplaca peltata emerges as a sister group to the L. muralis group, whereas $R$. chrysoleuca (the type species of the genus Omphalodina) branches as a sister group to the core group of Rhizoplaca species. The same branching pattern was also found with other outgroup taxa, such as members of the genera Tephromela M. Choisy, Parmelia Ach., and Hypogymnia (Nyl.) Nyl. (data not shown).

Interestingly, the lobate species L. novomexicana appears within the $R$. melanophthalma group, a position strongly supported by a bootstrap value of $98 \%$ (in the restricted analysis, 99\%). This group includes lobate and umbilicate species, as well as the more or less fruticose thallus types found in the vagrant species (Figs. 5-9). The latter confirms the earlier assumption that the North American vagrant morphotypes appear to be derived from the $R$. melanophthalma complex (Ryan and Nash 1997).

\section{Diversity of growth forms in Lecanora}

As is suggested in this study, the growth form of the thallus is a highly variable characteristic within family Lecanoraceae. In the study by Arup and Grube (1998), it was shown that the L. dispersa group and the Lecanora polytropa group include not only crustose members, but also lobate and more or less umbilicate species. The umbilicate thallus form, with both an upper and a lower cortex, as found in A. thuleana and in several Rhizoplaca species, seems to be derived from lobate thallus forms without a lower cortex that have been placed in subgenus Placodium of Lecanora.

A high degree of diversity in thallus morphology is found particularly in the core group of Rhizoplaca (Fig. 2). With our phylogenetic analysis, it remains unclear whether the thallus of L. novomexicana is a reduction of an umbilicate form (R. melanophthalma or a close relative) to a lobate thallus, or vice versa. More detailed investigations, including data from other genes, could address this question. It is likely that the umbilicate thallus developed into the various forms occurring in the vagrant species but, again, this needs to be confirmed by more data. Thalli of $R$. haydenii vary from fruticose-richly branched with narrow, more or less terete branches (or lobes) - to an almost globose structure formed by the folding of broader and flatter lobes (Fig. 5). The other vagrant species have rather flat and broad lobes that do not branch or branch very little (Figs. 6-9). The whole thallus mostly folds or coils so that the lower cortex, or lower side, cannot be seen. Although there are considerable differences in morphological characters, ITS sequence diversity is quite low. It might be suggested that this indicates efficient adaptation to particular habitats or environmental conditions. Furthermore, the positions of other species of Rhizoplaca, i.e., R. peltata and $R$. chrysophthal$m a$, which do not form a monophyletic group with the core group, indicate several independant origins for umbilicate growth in groups with lobate growth (Fig. 2).

The evolution of the foliose, umbilicate, or fruticose growth form is apparently correlated with the development of a true cortex as an "exoskeleton" (Poelt 1989, 1991). This type of cortex is found in various genera in the Lecanorales and has sometimes be used to characterize genera (e.g., Heppsora D.D. Awasthi \& K.P. Singh; Poelt and Grube 1993). In our analyses, the true cortex is found in different lineages in Lecanora, particularly in groups with lobate species. The development of foliose and fruticose thallus forms within lobate groups with true upper cortices appears to be a further consequence, and may be a response or adaptation to environment. Sun-exposed nutrient-rich rocks can be one such environment: A. thuleana inhabits coastal rocks manured by seabirds, while $R$. melanophthalma, $R$. peltata, and $R$. chry- 
Fig. 2. One of six most-parsimonious trees of a phylogenetic analysis of the ITS regions and the 5.8S region of groups within Lecanora that have usnic acid as a major secondary compound and with various growth forms, using Protoparmelia badia as the outgroup taxon. Bootstrap percentages greater than $50 \%$ are indicated. Thallus growth form represented by the terminal taxa is mapped directly on the tree in different shades of grey.
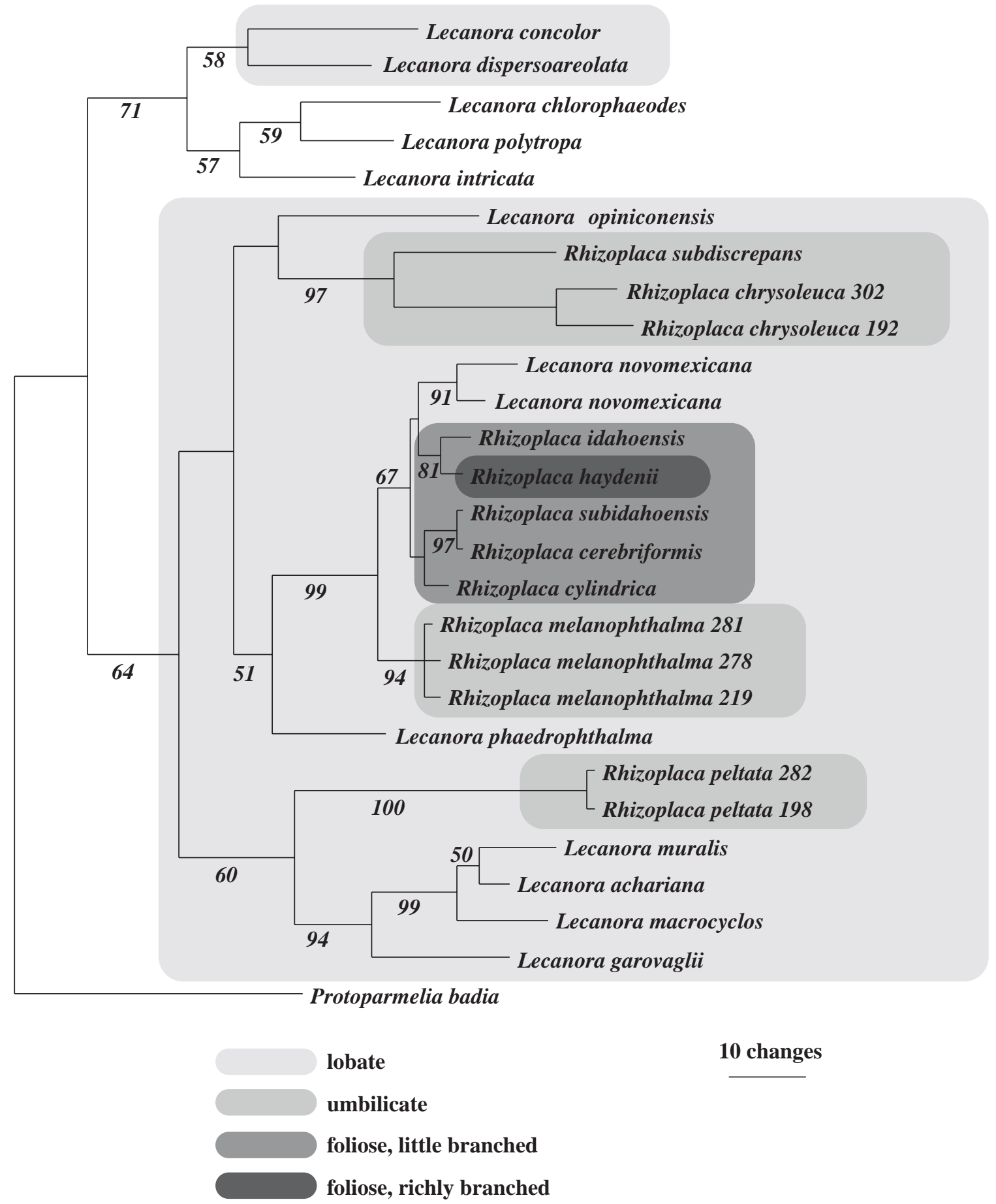

soleuca grow on exposed bird-manured rocks at higher altitudes. On the other hand, the vagrant species studied are found in windswept steppe-like communities, usually on calcareous gravel benches.

\section{The cupula and pycnidial characters}

In addition to the umbilicate thallus, Arctopeltis and Rhizoplaca both possess a cupulate structure below the hymenium.
Such a structure is also found in Lecanora opiniconensis, Lecanora bipruinosa, and P. badia. Roux et al. (1993) showed that the cupulate structure with more elongated hyphae found in Rhizoplaca and L. opiniconensis is distinct from the pseudoparenchymatous excipulum found in Parmelia, and does not deter the placing of these taxa in the Lecanoraceae. Also, the cupulate ascomatal structures of A. thuleana are different from those in Parmeliaceae (Feige 
Figs. 3-6. Appearance of some Rhizoplaca species. Fig. 3. Rhizoplaca chrysophthalma. Fig. 4. Rhizoplaca melanophthalma. Fig. 5. Rhizoplaca haydenii. Fig. 6. Rhizoplaca idahoensis. Scale bar $=5 \mathrm{~mm}$.
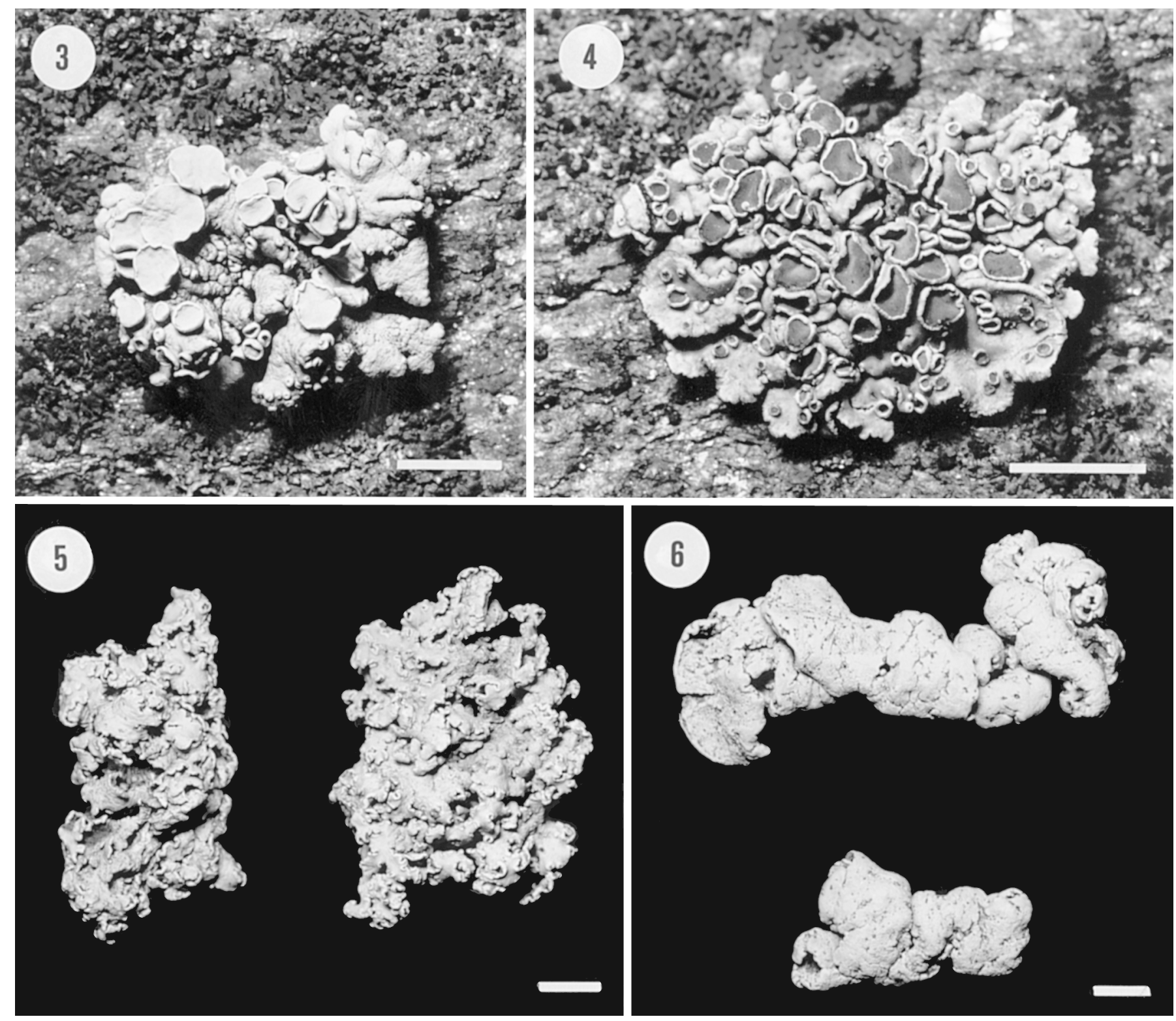

and Lumbsch 1998). In the present study, species possessing a cupulate hypothecium do not form one clade but occur in different lineages of Lecanora. These data suggest that the structure has developed several times independently, and mainly in groups with a higher degree of thallus organisation.

The type of conidiophores is constant in Lecanora, Rhizoplaca, and Arctopeltis, and this does not support separation of these genera from each other (Fig. 10). The conidiophores differ slightly from those in Protoparmelia M. Choisy (Fig. 11) and the Parmeliaceae (Fig. 12). The type of conidiophore found in Lecanora is often referred to as the "Placodium type," or type three (Vobis 1980); however, in our opinion, conidiophores of this type do not correspond particularly well with those found in Lecanora s.l., as they are branched and the conidia are produced acrogenously as well as pleurogenously. The type of conidiophores in Protoparmelia was one of the characters used to suggest a transfer of the genus to the Parmeliaceae (Henssen 1995), but the co- nidiophores appear to be more similar to those in Lecanora s.l. than to those in the Parmeliaceae. Most conidia in Lecanora and Rhizoplaca are filamentous and falcate. However, Lecanora saligna has broadly fusiform to arclike conidia that are distinct from the common type found in Lecanora. Nonetheless, the species branches well within Lecanora in the phylogenetic analysis.

\section{Secondary chemistry}

According to Leuckert et al. (1977), one of the reasons for treating Rhizoplaca as a genus of its own was that it was chemically homogeneous. They studied the secondary chemistry of $R$. chrysoleuca, $R$. melanophthalma, and $R$. peltata and found several chemical types within them (Table 3). Usnic acid was found in all three species, in addition to other compounds that were characteristic of each species, such as psoromic acid, placodiolic acid, pseudoplacodiolic acid, pannarin, and zeorin. 
Figs. 7-9. Appearance of some Rhizoplaca species. Fig. 7. Rhizoplaca subidahoensis. Fig. 8. Rhizoplaca cylindrica. Fig. 9. Rhizoplaca cerebriformis. Scale bar $=5 \mathrm{~mm}$.
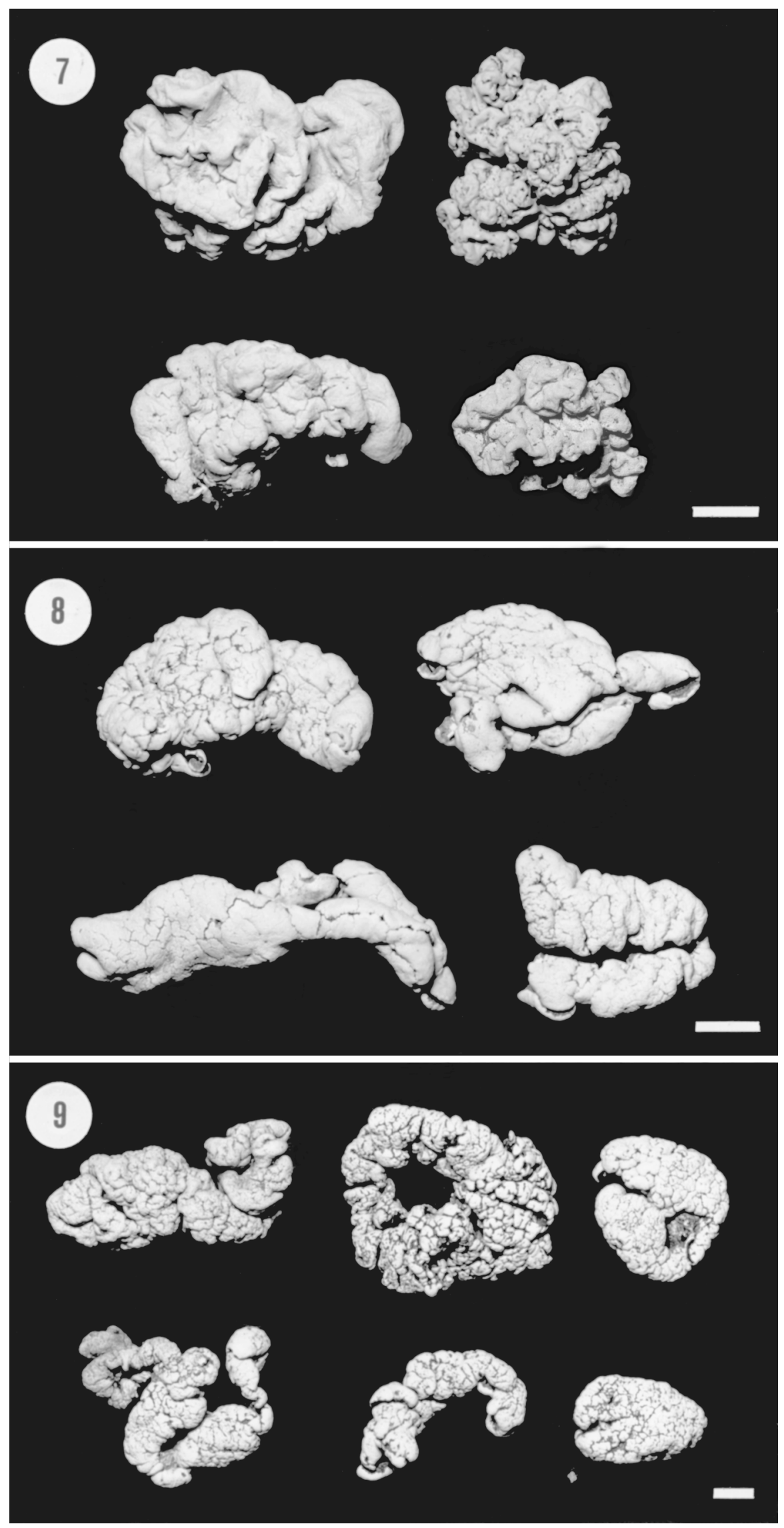
Figs. 10-12. Conidiophores and conidia. Fig. 10. Lecanora muralis. Fig. 11. Protoparmelia badia. Fig. 12. Pleurosticta acetabelum. Scale bar $=10 \mu \mathrm{m}$.

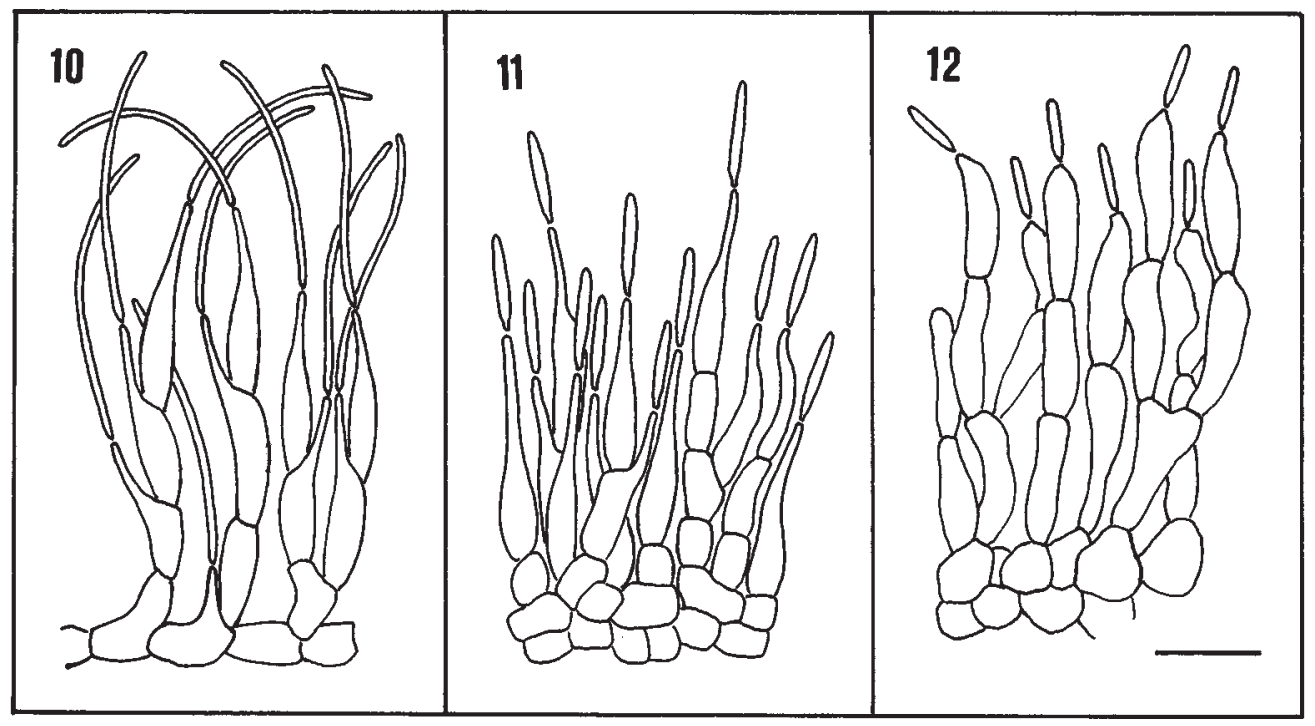

Table 3. Secondary chemistry of some species of Rhizoplaca and Lecanora; all species contain usnic acid in addition to the compounds shown.

\begin{tabular}{|c|c|c|c|c|c|c|c|c|c|}
\hline & $\begin{array}{l}\text { Placodiolic } \\
\text { acid }\end{array}$ & $\begin{array}{l}\text { Pseudo- } \\
\text { placodiolic acid }\end{array}$ & $\begin{array}{l}\text { Psoromic } \\
\text { acid }\end{array}$ & $\begin{array}{l}\text { Lecanoric } \\
\text { acid }\end{array}$ & Pannarin & $\begin{array}{l}\text { Norstictic } \\
\text { acid }\end{array}$ & Zeorin & $\begin{array}{l}\text { Terpenes or } \\
\text { triterpenes }\end{array}$ & Unknowns \\
\hline R. chrysoleuca & $x$ & $x$ & $(x)$ & $(x)$ & & & & & \\
\hline R. melanophthalma & & $(x)$ & $x$ & $(x)$ & & & & & \\
\hline R. peltata & $(x)$ & & $x$ & & $x$ & $(x)$ & $x$ & & \\
\hline R. subdiscrepans & $x$ & & & & & & & & \\
\hline L. novomexicana & & & & $(x)$ & & & & & \\
\hline L. muralis & & & $(x)$ & & & & $x$ & & \\
\hline
\end{tabular}

Note: " $x$ " indicates a major compound and " $(x)$ " indicates a compound found occasionally.

Psoromic acid, as well as usnic acid, is found in the lobate $L$. novomexicana, which is closely related to the core group of Rhizoplaca. However, at lower elevations in southwestern North America, lecanoric acid is often found instead of psoromic acid in this species. This chemistry corresponds very well with the compounds found in $R$. melanophthalma (compare Table 3 and McCune 1987). Other possible relatives of the Rhizoplaca core group included L. opiniconensis and Lecanora phaedrophthalma, but chemically these species do not fit into this group well. In the most-parsimonious trees, $L$. opiniconensis forms a branch with $R$. chrysoleuca and $R$. subdiscrepans (Figs. 1 and 2), but there is no significant bootstrap support and secondary chemistry indicates that $R$. chrysoleuca could be more closely related to the Rhizoplaca core group.

The grouping of $R$. peltata as sister to the $L$. muralis group is moderately supported by the bootstrap value of $71 \%$ (60\% in the restricted data set), as well as by the chemistry. Several members of the L. muralis group have both psoromic acid and zeorin in addition to usnic acid; pannarin does not occur in any of the species of the L. muralis group included in this study. On the other hand, psoromic acid and zeorin are common in Lecanora s.l. and their presence may not necessarily be considered very strong support for any relationship with $R$. peltata. The same is true for the related Rhizoplaca bullata, which was not included in this study. Morphologically, this species is closely related to R. peltata but it contains fumarprotocetraric acid (Follmann and Crespo 1976). This compound is also found sporadically in other groups of Lecanora species. These data indicate that the secondary chemistry does not support a monophyletic genus Rhizoplaca that is distinct from Lecanora. Other North American species not included in this study, such as Rhizoplaca glaucophana and Rhizoplaca marginalis, were transferred to Rhizoplaca by Weber (1979) but are chemically different (Brodo 1986).

The result that Rhizoplaca is not a monophyletic genus, if Lecanora is accepted in the current circumscription, has implications for the taxonomy of the Lecanoraceae. However, before we consider nomenclatural changes, we prefer to wait for additional support and information from other genes. Also, more genera related to Lecanora must be included in future analyses to develop a revised concept of the huge genus Lecanora; any resulting evaluation of generic segregates should then consider the criteria suggested by Nimis (1998). Here we can only outline possible scenarios. Including 
Rhizoplaca in the large genus Lecanora implies that additional genera ought to be considered as potential candidates for merging with Lecanora. On the other hand, if we agreed with Leuckert et al. (1977) that the difference between the L. allophana group and Rhizoplaca merits "more than generic rank," then we would face substantial taxonomic reorganisation and the generic splitting of lecanoroid lichens. In this case, the level at which genera should be segregated is still a matter of discussion. If Rhizoplaca s.s. were to include only the $R$. melanopthalma group and the vagrant species, then the generic name Omphalodina would have to be considered for the $R$. chrysoleuca group, and the L. muralis group could be merged with $R$. peltata under Protoparmeliopsis M. Choisy. We doubt, however, that this would be a good solution, since many other Lecanora species would then have an uncertain taxonomic position. In any case, a concept based on molecular data will lead to genera that are difficult to circumscribe with the traditionally used morphological characters. It is therefore important that phylogenetic studies at the genus level in the Lecanorales be accompanied by further investigation of non-molecular characters.

\section{Acknowledgements}

We are grateful to R. Rosentreter, T. Nash III, and B. Ryan for the loan of Rhizoplaca specimens. This work was supported by grant P11806-GEN of the Austrian Science Foundation to M.G.

\section{References}

Arup, U., and Grube, M. 1998. Molecular systematics of Lecanora subgenus Placodium. Lichenologist (London), 30: 415-425.

Brodo, I.M. 1986. A new lobate species of the lichen genus Lecanora (Ascomycotina, Lecanoraceae). Mycotaxon, 26: 309-317.

Choisy, M. 1929. Genres nouveaux pour la lichénologie dans le groupe des Lécanoracées. Bull. Soc. Bot. Fr. 76: 521-527.

Cubero, O.F., Crespo, A., Fatehi, J., and Bridge, P.D. 1999. DNA Extraction and PCR amplification method suitable for fresh, herbarium stored and lichenized fungi. Plant Syst. Evol. 216: 243-249.

Feige, G.B., and Lumbsch, H.T. 1998. The ascoma development in Arctopeltis thuleana (Lecanoraceae) and its systematic significance. Cryptogam. Bryol. Lichenol. 19: 147-154.

Follmann, G., and Crespo, A. 1976. Beobachtungen zum Vorkommen spanischer Flechten V. Eine neue Schildflechte aus dem Verwandtschaftskreis von Omphalina rubina (Vill.) Choisy. Philippia, 3: 24-29.

Gardes, M., and Bruns, T.D. 1993. ITS primers with enhanced specificity for basidiomycetes - application for the identification of mycorrhizae and rusts. Mol. Ecol. 2: 113-118.

Hafellner, J. 1984. Studien in Richtung einer natürlicheren Gliederung der Sammelfamilien Lecanoraceae and Lecideaceae. Beihefte zur Nova Hedwigia, 79: 241-371.

Henssen, A. 1995. Apothecial structure and development in Protoparmelia badia (Parmeliaceae s.lat.). In Flechten Follmann: contributions to lichenology in honour of Gerhard Follmann. Edited by F.J.A. Daniels, M. Schulz, and J. Peine. Geobotanical and
Phytotaxonomical Study Group, Botanical Institute, University of Cologne, Cologne. pp. 55-62.

Kishino, H., and Hasegawa, M. 1989. Evaluation of the maximum likelihood estimate of the evolutionary tree topologies from DNA sequence data, and the branching order in Hominoidea. J. Mol. Evol. 29: 170-179.

Leuckert, C., Poelt, J., and Hähnel, G. 1977. Zur Chemotaxonomie der eurasischen Arten der Flechtengattung Rhizoplaca. Nova Hedwigia, 28: 71-129.

Lumbsch, T.H., Schmitz, K.E., and Feige, G.B. 1991. "Lecanora" opiniconensis: a placodioid member of the Parmeliaceae (lichenized Ascomycotina). Mycotaxon, 42: 77-87.

McCune, B. 1987. Distribution of chemotypes of Rhizoplaca in North America. Bryologist, 90: 6-14.

Nimis, P.L. 1998. A critical appraisal of modern generic concepts in lichenology. Lichenologist (London), 30: 427-438.

Poelt, J. 1958. Die lobaten Arten der Flechtengattung Lecanora Ach. in der Holarktis. Mitt. Bot. Staatssamml. Muench. 2: 411-573.

Poelt, J. 1983. Über den Formenkreis der Flechte Lecanora contractula. Int. J. Mycol. Lichenol. 1: 143-160.

Poelt, J. 1989. Die Entstehung einer Strauchflechte aus einem Formenkreis krustiger Verwandter. Flora (Jena), 183: 65-72.

Poelt, J. 1991. Homologies and analogies in the evolution of lichens. In Frontiers in mycology. Edited by D.L. Hawksworth. Commonwealth Agricultural Bureaux International, Kew, U.K. pp. 85-97.

Poelt, J., and Grube, M. 1993. Beiträge zur Kennntnis der Flechtenflora des Himalaya VI. Die Gattung Tephromela (mit Bemerkungen zum Genus Heppsora). Nova Hedwigia, 57: 1-17.

Roux, C., Coste, C., Ménard, T., Bellemère, A., and Bricaud, O. 1993. Lecanora vaenskei Roux et C. Coste sp.nov. (Lichens, Ascomycotina), sa position systématique et celle des Rhizoplaca (Lecanorales, Lecanoraceae). Can. J. Bot. 71: 1660-1671.

Ryan, B.D., and Nash, T.H., III. 1997. Placodioid taxa of Lecanoraceae sensu Zahlbr. (lichenized Ascomycotina) in North America: taxa excluded from Lecanora subgen. Placodium. Nova Hedwigia, 64: 393-420.

Stenroos, S.K., and DePriest, P.T. 1998. SSU rDNA phylogeny of cladoniiform lichens. Am. J. Bot. 85: 1548-1559.

Swofford, D.L. 1999. Phylogenetic analysis using parsimony (*and other methods). Version 4.0b2. Sinauer Associates, Sunderland, Mass.

Thell, A., and Goward, T. 1996. The new cetrarioid genus Kaernefeltia and related groups in the Parmeliaceae (lichenized Ascomycotina). Bryologist, 99: 125-136.

Vobis, G. 1980. Bau und Entwicklung der Flechten-Pycnidien und ihrer Conidien. Bibl. Lichenol. 14: 1-141.

Weber, W.A. 1979. New combinations in Rhizoplaca for endemic American species of Lecanora auct. Mycotaxon, 8: 559-560.

White, T.J., Bruns, T.D., Lee, S., and Taylor, J. 1990. Amplification and direct sequencing of fungal ribosomal DNA genes for phylogenies. In PCR protocols. Edited by M.A. Innis, D.H, Gelfand, J.J. Sninsky, and T.J. White. Academic Press, San Diego. pp. 315-321.

Zahlbruckner, A. 1926. Lichenes (Flechten). B. Spezieller Teil. In Die Natürlichen Pflanzenfamilien. Bd. 8. Aufl. 2. Edited by A. Engler. Engelmann, Leipzig. pp. 61-270.

Zopf, W. 1905. Zur Kenntnis der Flechtenstoffe. 14. Mitt. Ann. Chem. 340: 276-309. 